\title{
Changing Paradigms of Open and Distance Learning System with Blended Learning: Indian National Education Policy, 2020
}

\section{Noor Aisha ${ }^{1}$ and Amiteshwar Ratra ${ }^{2 *}$}

\author{
${ }^{1}$ Research Scholar, STRIDE, Indira Gandhi National Open University, New Delhi, India \\ ${ }^{2}$ Associate Professor, STRIDE, Indira Gandhi National Open University, New Delhi, India \\ *Corresponding author: amiteshwar@ignou.ac.in
}

Received: 14 Oct., 2020

Revised: 19 Nov., 2020

Accepted: 02 Dec., 2020

\begin{abstract}
Purpose: The Open and Distance Learning (ODL) system has been integrating technology to reach the students since the inception of technology. The efforts to integrate technology in the education sector have always been to bring about quality enhancements and outreach of education to learners at a distance. The ODL system in the context of India has grown from past six decades leading to the changing paradigms with the integration of technology with respect to pedagogy and the use of technology in it. The ODL system has benefitted India in contributing to increase the Gross Enrolment Ratio of the country. Thus, the present research intends to study the evolution of distance education from merely technology mediated to the blended learning approach; the potential of blended learning in leveraging the teachinglearning process; and the role of the new National Education Policy (NEP, 2020) of India has laid emphasis on the promotion and implementation of blended learning in the Indian higher education institutions.
\end{abstract}

Design/Methodology/Approach: This study employs document analysis to study how the evolution of distance education took place; and the role of the National Education Policy (2020) in leveraging blended learning in the Indian higher education Institutions.

Findings: The $21^{\text {st }}$ century world of ever developing science and technology requires a robust and upgraded educational system to cope with the advancements and challenges. This study finds blended learning as a mode of teaching-learning that can be relied for teaching-learning process. Further, the paper observes how the various factors that include the technological

How to cite this article: Aisha, N. and Ratra, A. (2020). Changing Paradigms of Open and Distance Learning System with Blended Learning: Indian National Education Policy, 2020. Learning Community, 11(2): 91-100. 
and pedagogical advancements of ODL system which includes online and blended learning, National Education Policy (2020), and the COVID-19 pandemic have a mixed impact in promoting and implementation blended learning in the Indian higher education institutions.

Originality/Value: This paper is an original work that reviews and discusses the changing paradigms of ODL from correspondence education to online and blended learning. And, highlights the major thrust areas of blended learning in Indian new National Education Policy (NEP 2020), through which India foresees to achieve sustainability in the education system through ODL, as it thrusts largely for blended learning.

Keywords: Open and Distance Learning (ODL), Online Learning, Blended Learning, National Education Policy (NEP) 2020, and COVID-19 pandemic.

Distance education means learning distantly, without direct contact with teacher in the regular classroom (Keegan, 1980). Distance Education has often attributed with a number of other terms such as distributed learning, e-learning, online learning, etc, however distance education is preferred (Moore, et al, 2010). It includes the process of distance learning and distance teaching. It extensively allows a learner the maximum favours to continue the learning, and a dedicated support to match and balance the process of learning with his work and personal life, where the learner can (usually) set his own pace of study, can decide as to when and where to study. It doesn't hinder a learner to acquire knowledge and a degree from anywhere in the world. A learner can study undergraduate, postgraduate and professional level courses through distance education. University Grants Commission has ensured that degree from both distance education university as well as conventional system is considered at par (UGC, 2013). Distance education gives the learner ample opportunities of new choices and new found suppleness and flexibility with their personal learning and development (Marty, 2014). The learner gets benefitted with greater educational access and greater flexibility to learn and get qualified without having regular scheduled classes, and even when there are lots of other personal commitments to deal with in an already busy life. Also, as distance education can usually be completed on the learner's own schedule, hence it is much easier to complete distance courses while working than more traditional educational programs (Marty, 2014).

Such limitless opportunities of flexibility have been possible due to the technology integration in the distance education (Bates, 2005). students can study from their homes to complete their class assignments provided there's a computer and internet connection at home (Marty, 2014). The stakeholders of distance education have started to use the technology parallelly with the advancements of ICTs. Distance education also employs some portion of face-to-face interactions as per the requirement of the programme. Such inclusion of face-to-face with distance education and simultaneous expansion of ICTs and its integration has blurred all the boundaries giving it a blended format of education (Oliver \& Trigwell, 2005; Driscoll, 2002). 
The conventional education system seems to be in evolving phase today, as it is developing with the help of information and communication technology and its use in the educational process. The conventional classrooms were also found to use virtual classrooms which were a part of the distance education platform, which signifies the common elements in conventional and distance, however distance education was sometimes found better in providing quality education to large numbers than the conventional system of education (Bates, 2005) due technological interventions. In this technological world, there seems no boundaries of conventional and distance education in the near future which is heading towards the blended mode of education.

Distance education has evolved technologically and pedagogically in order to provide the learner an education that can meet the personal needs, strengths and career goals (Aoki, 2012). The distance education has witnessed the changing paradigms from correspondence education to online and blended learning due to the technology mediated education (Bates, 2005). Dikshit, Garg and Panda (2013) opined that adoption of blended learning will be beneficial to learners by providing enhanced learning experience by using interactive multimedia, supported by printed booklets, discussion forums and activities using World Wide Web (Dikshit, Garg and Panda, 2013, p. 208). It has been further observed that National Education Policy (2020) envisions for the technological interventions (Aithal and Aithal, 2020a; Mitra \& Singh, 2020) in the curriculum and the course designs to provide new and/or reform the various programmes to be offered in online and blended learning and to achieve sustainability (Aithal and Aithal, 2020b) in the education system through open and distance learning (ODL), with it thrusts on blended learning.

Thus, the objectives of the present research were to study:

how distance education evolves from technology mediated to the blended learning;

how blended learning can leverage the teaching-learning process; and,

how the National Education Policy, 2020 promoting blended learning in the Indian higher education system.

Acronyms used in the paper:

ODL - Open and Distance Learning

NEP - National Education Policy

\section{Research Methodology}

This study is based on qualitative research method using document analysis (Bowen, 2009) to study how the evolution of distance education took place; to analyze paradigm shift in open and distance learning in light of the National Education Policy, 2020 in leveraging blended learning in the Indian higher education system. 


\section{RESULTS AND DISCUSSION}

\section{Evolution of Distance Education to Blended Learning}

Distance education has been defined and elaborated by various researchers in different ways. Keegan (1980) has distinguished distance education from traditional education in terms of six characteristics i.e., teacher-learner separation, educational organization influence planning and student support, media usage, two-way communication, participation in an industrialized form of education and, learner as individual or privatization of learning.

Peter (1973) as well as Bates (2005) described distance education had undergone three stages (Aoki, 2012). According to Taylor (2001), distance education has evolved through five generations on the basis of dominant technology and with the transformation of media. These five generations of distance education given by Taylor (2001), were analysed and presented here in Table 1.

Table 1: Five generations of Distance Education (DE)- on the basis of dominant technology (Taylor, 2001)

\begin{tabular}{|c|c|c|}
\hline & Generation & Characteristics \\
\hline \multirow{5}{*}{ 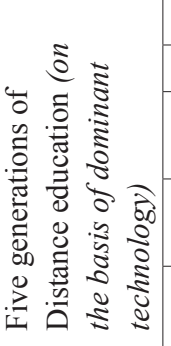 } & The Correspondence Model & It is based on print technology \\
\hline & The Multi-media Model & It is based on print as well as audio-video technologies \\
\hline & The Tele-learning Model & $\begin{array}{l}\text { It made the use and application of telecommunication } \\
\text { technologies that facilitates synchronous communication }\end{array}$ \\
\hline & The Flexible Learning Model & $\begin{array}{l}\text { It is based on online delivery of instructional material over } \\
\text { the internet }\end{array}$ \\
\hline & The Intelligent Flexible Learning Model & $\begin{array}{l}\text { It makes the use of interaction facilitated by internet. While, } \\
\text { on the basis of dominant pedagogy }\end{array}$ \\
\hline
\end{tabular}

While, on the basis of dominant pedagogy, distance education was categorised in three generations by Anderson and Dron (2011). These three generations of distance education based on the dominant pedagogy as given by Anderson and Dron (2011), were analysed and presented here in Table 2.

Table 2: Three generations of Distance Education (DE)- on the basis of dominant pedagogy by Anderson and Dron (2011)

\begin{tabular}{|c|c|c|}
\hline & Generation & Characteristics \\
\hline \multirow{3}{*}{ 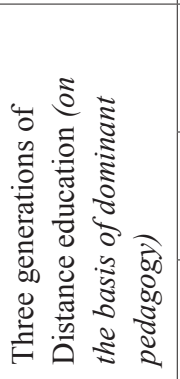 } & Cognitivist-behaviourist pedagogy & $\begin{array}{l}\text { It focusses to prompt learning by a learning stimulus by bringing } \\
\text { about some behavioural changes which is characterised by the } \\
\text { computer-assisted instruction in the instructional systems designs. }\end{array}$ \\
\hline & Social constructivist pedagogy & $\begin{array}{l}\text { The generation of social constructivist pedagogy is mainly } \\
\text { categorised by the learners' social interactions with their teachers } \\
\text { and other learners. }\end{array}$ \\
\hline & Connectivist pedagogy & $\begin{array}{l}\text { The connectivist pedagogy is based on the social interactions, } \\
\text { collaborations to make networked connections in the digital era } \\
\text { and ensure the learners' participation in it. }\end{array}$ \\
\hline
\end{tabular}


According to Aoki (2012), distance education has become more and more flexible, interactive, and accessible. In present times, all the generations of distance education do exist and all of these generations are being in use too, and none of these generations of distance education had been eliminated over time (Anderson and Dron, 2012; Aoki, 2012). Thereby, a shift in learning theory and pedagogy has occurred (Aoki, 2012); and thus, the understanding of effective, quality education has evolved. Online programs are considered to evolved from traditional distance learning programs and represent the latest evolution in distance learning. Therefore, most educators and researchers consider 'Online learning' as a subset of distance learning, where the students and teacher are geographically separate, in which content delivery and communication are achieved primarily through the use of computers connected by the Internet.

It is seen in the past few years that the evolution of distance education systems, has given an impetus to blended learning. Blended learning is believed to be a combination of elements of in-person teaching with technology-enabled learning to bring people together (Cleveland-Innes \& Wilton, 2018; Vaughan, 2010). Blended learning is the combination of distance learning, face-to-face and online/e-learning making it a new, robust instructional approach that takes advantage of the best elements of both distance and face-to-face settings (Watson, 2008) with synchronous/asynchronous online/e-learning. Consequently, the term "blended learning" is now-a-days used worldwide, with a greater velocity in the educational settings, which has greatly increased the quality of learning and instruction.

\section{Blended learning leveraging teaching-learning process}

Different educationists describe Blended learning in various ways. The stakeholders of conventional education consider it a mix of some technological interventions with the traditional face-to-face instruction (Turugare, M. and Rudhumbu, N., 2020). Blended learning combines classroom learning with online learning. It allows in proportion, the students to work on individualized basis through online instruction (Tabor, 2007). However, the evolved and the advanced form of Distance Education considers the synchronously and/or the asynchronously instruction mediated combinedly, as Blended learning. According to Oliver and Trigwell (2005), the term blended learning is found inconsistently used and 'ill-defined'; as well as there is found no consensus on single definition for blended learning (Oliver and Trigwell, 2005), however, its potential is never denied.

Blended learning is an instructional methodology (Power, 2008) that leverages technology to provide a more personalized approach to learning, giving students control over the time, place, path and pace of their learning. Blended learning found to have a positive effect in reducing dropout rates and in improving exam marks (Ginns and Ellis, 2007), and the students' perception on blended learning are interrelated with their final marks depending on the blended learning activities, and on the students' age, background and class attendance rate (Lopez et al. 2011).

According to Garrison and Kanuka (2004) blended learning has the potential to provide the meaningful learning experiences by enhancing the effectiveness and efficiency of the instruction; and is unfailing and reliable with the values of traditional higher education institutions (Garrison and Kanuka, 2004). In a meta-analysis, Means et al. (2013) found that the learners who experienced an additional online 
learning are performing somewhat better than the learners who are receiving the face-to-face instruction only. The studies conducting the comparison between blended learning and traditional face-to-face learning concluded that blended learning is a significant advantage in imparting instruction, however it was not found in the cases comparing purely online instruction and face-to-face classes (Means et al, 2013). Instructions imparted through blended learning methods had improved pedagogy, increased access to knowledge, fostered social interaction, increased the amount of teacher presence during learning, improved cost effectiveness, and enhanced ease of revision (Osguthorpe and Graham, 2003). It is also observed by Picciano (2009) that blended learning models allows a learner to experience learning with flexibility to make them comfortable in the learning process, as well as to make them experience learning in the new challenging ways. According to Rajkoomar and Raju (2016), blended learning is found to have the wide acceptance with respect to its capability in delivering personalized learning; but to impart an enhanced learning experience with blended learning, it must be designed to meet the individual needs of learners of a particular discipline (Rajkoomar and Raju, 2016), with a strong institutional support and a focussed policy to foster an effective teaching-learning in blended mode (Gaeta et al. 2009).

\section{Role of NEP 2020 in promoting Blended Learning}

India, in the present $21^{\text {st }}$ century world of ever developing science and technology requires a robust and upgraded educational system to cope with the advancements \& challenges, and to achieve sustainability (Kumar, Prakash and Singh, 2020). The NEP (2020) envisages the extensive use of educational technology at all levels in its education system. For ensuring this extensive use of educational technology and fulfilling the requirements of technology integration and implementation of e-education, for capacitybuilding at both school and higher education institutions across the country. And, the University Grants Commission (UGC) has directed all the Indian higher education institutions to implement the enhanced technological interventions in the educational transactions (Nandini, 2020).

Technology integration will also include the learning of different languages of India by preparing and disseminating the Online modules of the classical languages and literatures of India, B. Ed. And all other teacher training including the Continuous Professional Development (CPD) programmes for teachers, special education, Professional \& Vocational, including Agriculture, Veterinary Science, Legal Education programmes, Adult Education \& Life-long Learning programmes will also be made available in new Instructional Online modules and those Online modules are to be guided to be mixed and integrate in the conventional programmes to offer new programmes/courses in Blended Learning format by all the Higher Education Institutions (HEIs) as well as Open \& Distance Learning (ODL) institutions to appropriately amalgamate all the programmes with a multidisciplinary approach to integrate core disruptive technologies in undergraduate and Post-Graduate (PG) level. All such online modules through the experiential and innovative approaches, will be made available in blended format to offer it to the learners as an elective subject.

The NEP (2020), suggests to carry out the research to ensure the implementation of new advancements of technology into educational process. Various institutions/agencies like National Education Technology 
Forum (NETF), Indira Gandhi National Open University (IGNOU), Central Institute of Educational Technology (CIET), National Council of Educational Research \& Training (NCERT), National Institute of Open Schooling (NIOS), Indian Institute of Technology (IITs), National Institute of Technology (NITs) etc. are being directed to carry out the pilot studies for integrating online/digital education in the curriculum at various levels, to develop formats of e-contents and evaluate their benefits while mitigating their shortcomings.

NEP (2020) has advised the States, Boards, Schools, Higher Education Institutions or the appropriate bodies like NETF (Baral, 2020) to formulate the guidelines to set up the standards for content, pedagogy and technology in the curriculum. And, it is in the coherence of the pedagogical point of view that supports for the integration of technology in education according to TPACK framework (Mishra \& Koehler, 2006), which is commonly required/taken up by the educators to identify the three types of knowledge i.e., Technological, Pedagogical, and Content Knowledge for effective pedagogical practices in a technology-enhanced teaching-learning environment.

The major recommendations of the NEP (2020) include and supports the idea to blend the various online course with the traditional learning courses. Since, blended learning combines the online and the traditional learning and focusses on the social, affective and psychomotor dimensions of learning, it would be helpful in providing the experiential and activity-based learning. The NEP (2020) encourages the higher education institutions to identify the various models of Blended learning to offer various subjects in Blended mode to promote digital learning and education and the importance of face-to-face in-person learning. And, to provide suitable training to the teachers to become an effective online educator.

Other areas that have been focussed in NEP (2020) includes the development of various educational software, a repository for e-contents in multiple languages, establishment of digital libraries and virtual labs (Baral, 2020) to enhance the access for all learners and to provide them equal opportunities for the hands-on practical and to experience the experiment-based learning environment. As disruptive technologies are emerging in present scenario, spreading awareness of their potential and disruptive effects is a requirement. Therefore, suitable instructional materials will also be prepared for schooling as well as for continuing education.

The new education policy favours the advanced learning experiences through Learning games and Simulations etc. to provide the learning through Augmented and Virtual Reality in multiple languages.

Thus, it is observed that NEP (2020) is pointing towards the rise of emerging technologies and encourages its integration at all levels of education in addition to all other basic infrastructural needs, NEP (2020) thrusts that every institution in India should be equipped with the latest digital tools for the implementation of educational technology at all levels that enables all the learners to have better opportunities for access and enhanced learning experiences. Also, it recommends to extensively and suitably integrate the technology to ensure efficiency in all spheres of teaching-learning, for which blended learning is the instructional modality which can caters all the technological and pedagogical requirements. 


\section{CONCLUSION}

It is concluded that the technological interventions, NEP 2020 and the COVID-19 pandemic have a mixed impact in promoting and implementation of Blended learning in the Indian education institutions. NEP (2020) thrust to offer various courses in blended mode. Blended learning can help in leveraging teaching-learning process that can meet the learning needs of a learner, requirements of an instructor as well as the pedagogical factors. Conventional face-to-face programmes can be modified to fit a blended format. There is no single formula to make any programme to blended format. Since every programme is unique and so, it will require different attributes in varying proportions to make it blended. And, blended learning strategies will be a standard method of instructional delivery if designed and implemented through careful planning, time and practice.

\section{REFERENCES}

1. Aithal, S. and Aithal, S. 2020a. Analysis of the Indian National Education Policy 2020 towards Achieving its Objectives. International Journal of Management, Technology, and Social Sciences (IJMTS), 5(2): 19-41.

2. Aithal, S. and Aithal, S. 2020b. Implementation Strategies of Higher Education Part of National Education Policy 2020 of India towards Achieving its Objectives. International Journal of Management, Technology, and Social Sciences (IJMTS), 5(2): 283-325.

3. Anderson, T. and Dron, J. 2012. Learning Technology through Three Generations of Technology-enhanced Distance Education Pedagogy, European Journal of Open, Distance and E-Learning, 2. Retrieved from https:// eric.ed.gov/?id=EJ992485 accessed on 03/10/2020.

4. Anderson, T. and Dron, J. 2011. Three Generations of Distance Education Pedagogy, International Review of Research in Open and Distance Learning, 12(3): 80-97.

5. Aoki, K. 2012. Generations of Distance Education and Challenges of Distance Education Institutions in Japanese Higher Education. Retrieved from https://www.intechopen.com/books/distance-education/generations-of-distanceeducation-and-challenges-of-distance-education-institutions-in-japanese-high accessed on 03/12/2020

6. Baral, M. 2020. New Education Policy Moots Formation of Technology Forum. NDTV. Retrieved from https:// www.ndtv.com/education/new-education-policy-moots-formation-of-technology-forum accessed on 03/08/2020.

7. Bates, T. 2005. Technology, e-learning and distance education: Routledge Falmer. Retrieved from https://books. google.co.in/books?hl=en\&lr=\&id=w8xIPSTfZBUC\&oi=fnd\&pg=PP8\&dq=Bates + T. + Technology, + e-learning + an $\mathrm{d}+$ distance+education:+RoutledgeFalmer\%3B+2005.\&ots=fRdjpBcJV2\&sig=TNH4GfHWoMwD2h4IBpp5T9iULE\&redir_esc $=\mathrm{y} \# \mathrm{v}=$ onepage $\& \mathrm{q} \& \mathrm{f}=$ false accessed on $08 / 10 / 2020$.

8. Bowen, Glenn. 2009. Document Analysis as a Qualitative Research Method. Qualitative Research Journal. 9. 27-40. 10.3316/QRJ0902027. Retrieved from https://www.researchgate.net/publication/240807798_Document_Analysis_ as_a_Qualitative_Research_Method accessed on 06/10/2020.

9. Cleveland-Innes, M. and Wilton, D. 2018. Guide to Blended Learning. Commonwealth of Learning. Retrieved from http://oasis.col.org/bitstream/handle/11599/3095/2018_Cleveland-Innes-Wilton_Guide-to-Blended-Learning. pdf? sequence $=1 \&$ isAllowed $=y$ accessed on 12/06/2020. 
10. Dikshit, J., Garg, S. and Panda, S. 2013. Pedagogic Effectiveness of Print, Interactive Multimedia, and Online Resources: A Case Study of IGNOU. International Journal of Instruction, 6(2): 193-210.

11. Driscoll, Margaret. 2002. Blended learning: Let's get beyond the hype. E-learning. 3. Retrieved from https://www. researchgate.net/publication/286029739_Blended_learning_Let's_get_beyond_the_hype accessed on 04/10/2020.

12. Gaeta, M. et al. 2009. Advanced ontology management system for personalised e-Learning. Knowledge-Based Systems, 22(4): 292-301.

13. Garrison, D.R. and Kanuka, H. 2004. Blended learning: uncovering its transformative potential in higher education. The Internet and Higher Education, 7(2): 95-105.

14. Ginns, P. and Ellis, R. 2007. Quality in blended learning: Exploring the relationships between on-line and face-toface teaching and learning. Internet and Higher Education, 10: 53-64.

15. Keegan, Desmond J. 1980. On defining distance education, Distance Education, 1(1): 13-36.

16. Kumar, K., Prakash, A. and Singh, K. 2020. How National Education Policy 2020 can be a lodestar to transform future generation in India. DOI https://doi.org/10.1002/pa.2500. Retrieved from https://onlinelibrary.wiley.com/ doi/abs/10.1002/pa.2500 accessed on 04/10/2020.

17. Lopez, V., Pérez-López, M. and Rodríguez-Ariza, Lazaro. 2011. Blended learning in higher education: Students' perceptions and their relation to outcomes. Computers \& Education, 56: 818-826.

18. Marty, O. 2014. Monetizing French Distance Education. Retrieved from https://www.researchgate.net/ publication/278620805_Monetizing_French_Distance_Education accessed on 10/10/2020.

19. Means, B. et al. 2013. The Effectiveness of Online and Blended Learning: A Meta-Analysi of the Empirical Literature. Teachers College Record, 115.

20. Mitra, Y. and Singh, D. 2020. NEP 2020: An Interplay of Education and Technology. India Corporate Law-A Cyril Amarchand Mangaldas Blog. Retrieved from https:/corporate.cyrilamarchandblogs.com/2020/08/nep-2020-aninterplay-of-education-and-technology/ accessed on 12/09/2020.

21. Mishra, P. and Koehler, M.J. 2006. Technological Pedagogical Content Knowledge: A new framework for teacher knowledge. Teachers College Record, 108(6): 1017-1054.

22. Moore, J., Dickson-Deane, Camille \& Galyen, K. and Chen, W. 2010. Designing for E-learn, Online, and Distance Learning Environments: Are They the Same? Retrieved from https://www.researchgate.net/publication/233751524_ Designing_for_E-learn_Online_and_Distance_Learning_Environments_Are_They_the_Same/citation/download accessed on $12 / 10 / 2020$.

23. Nandini. 2020. "UGC ask varsities to create awareness about new education policy among students, teachers". Hindustan Times. Retrieved from "UGC ask varsities to create awareness about new education policy among students, teachers". (Accessed on 6/08/2020)

24. National Education Policy. 2020. Ministry of Human Resource \& Development. Government of India. Retrieved from https://www.mhrd.gov.in/sites/upload_files/mhrd/files/NEP_Final_English_0.pdf accessed on 01/10/2020

25. Oliver, M. and Trigwell, K. 2005. Can 'Blended Learning’ Be redeemed? E-Learning, 2(1): 17-26.

26. Osguthorpe, T.R. and Graham, R.C. 2003. Blended learning environments: Definitions \& Directions. Quarterly Review of Distance Education, 4(3): 227-233. 
C Aisha and Ratra

27. Picciano, A.G. 2009. Blending with Purpose: The Multimodal Model. DOI. JALN. 13. 10.24059/olj.v13i1.1673. Accessed on $02 / 10 / 2020$.

28. Power, M. 2008. The Emergence of a Blended Online Learning Environment. MERLOT Journal of Online Learning and Teaching, 4(4): 503-514.

29. Rajkoomar, M. and Raju, J. 2016. A Framework Using Blended Learning for Innovative Teaching and Learning. Retrieved from https://www.semanticscholar.org/paper/A-Framework-Using-Blended-Learning-for-InnovativeRajkoomar-Raju/869658d450e9b0f7e3212e636b56431c7ea2f46b accessed on 12/10/2020

30. Tabor, Sharon W. 2007. "Narrowing the Distance: Implementing a Hybrid Learning Model". Quarterly Review of Distance Education, 8(1): 47-57.

31. Taylor, J.C. 2001. Fifth generation distance education. e-Journal of Instructional Science and Technology (e-JIST), 4(1): $1-14$.

32. Turugare, M. and Rudhumbu, N. 2020. Integrating technology in teaching and learning in universities in Lesotho: opportunities and challenges. Educ. Inf. Technol., 25: 3593-3612.

33. UGC. 2013. https://www.ugc.ac.in/deb/notices/ODLEquivalenceDegrees.pdf accessed on 21/10/2020.

34. Vaughan, Norman D. 2010. "Blended Learning”. In Cleveland-Innes, MF; Garrison, DR. An Introduction to Distance Education: Understanding Teaching and Learning in a New Era. Taylor \& Francis. p. 165. ISBN 0-415-99598-1. Accessed on 25/10/2020.

35. Watson, J. 2008. Blended Learning: The Convergence of Online and Face-to-face Education. Promising Practices in Online Learning, pp. 1-16. 